\title{
To understand a meta-analysis, best read the fine print.
}

\author{
Kevin Greason ${ }^{1}$ \\ ${ }^{1}$ MAYO CLINIC
}

September 27, 2021

\begin{abstract}
The results of a meta-analysis are more than just the reported odds ratio, 95\% confidence interval, and $\mathrm{P}$ value. Of equal importance is the fine print of the study which should include assessment of risk of bias, certainty in evidence, and heterogeneity in the individual point estimates and confidence intervals. These areas all have influence on the quality of the data in the analysis. Reading and understanding the fine print is important.
\end{abstract}

\section{Hosted file}

JOCS-2021-RA-875.docx available at https://authorea.com/users/322991/articles/539369-tounderstand-a-meta-analysis-best-read-the-fine-print 